IBAD Sosyal Bilimler Dergisi

IBAD, 2019; (5): 9-21

DOI: 10.21733/ibad.559860

Özgün Araştırma / Original Article

\title{
Beş Faktör Kişilik Özelliklerinin İş Tatmini Üzerindeki Etkisinde Depresyonun Aracılık Rolü
}

\section{Dr. Özge Turhan ${ }^{1 *}$}

Geliș tarihi: 03.05.2019

Kabul tarihi: 22.06.2019

\section{Atıf bilgisi:}

IBAD Sosyal Bilimler Dergisi

Sayı:5 Sayfa: 9-21

Yıl: 2019 Dönem: Güz

This article was checked by Turnitin. Similarity Index 21\%

${ }_{1}^{1}$ Türkiye, ozge.turhan@yahoo.com. ORCID ID 0000-0001-5072-2712

\section{* Sorumlu yazar}

\begin{abstract}
ÖZ
$\mathrm{Bu}$ çalıșmanın temel amacı, beș faktör kișilik özellikleri ile iș tatmini arasındaki etkileşimde depresyonun rolünü tespit etmektir. Beş faktör kişilik özellikleri ile iş tatmini arasındaki etkileşimde depresyonun rolüne ilişkin araştırma İstanbul ilinde faaliyet gösteren çeşitli sektörlerde çalışan mavi ve beyaz yakalı işgörenlere yönelik gerçekleștirilmiștir. 523 gönüllüden elde edilen verilerden 23 adeti uç veri barındırdığından analizler 500 geçerli anket üzerinden gerçekleştirilmiştir. Gerçekleștirilen analizler sonucu; depresyon ile nevrotizm arasında pozitif yönlü anlamlı ilişki olduğu tespit edilmiştir. Depresyonun iş tatmininin her iki alt boyutuyla negatif, iş tatmininin dişadönüklük, gelişime açlklık, sorumluluk/uyumluluk özellikleriyle ise pozitif yönlü anlamlı ilişkisi olduğu saptanmıştır. Gerçekleştirilen hiyerarşik çoklu regresyon analizi sonucu; beş faktör kişilik özelliklerinin iş tatmini üzerindeki etkisinde depresyonun kısmi aracılık etkisi olduğu tespit edilmiștir. Fark analizi sonuçları; yaş ilerledikçe, kıdem arttıkça, ücret ve eğitim seviyesi düştükçe yaşanan depresyonun arttığı saptanmıştır. Eğitim seviyesi arttıkça işgörenlerin gelişime açık ve dışadönük oldukları, sorumluluk/uyumluluk daha fazla gösterdikleri tespit edilmiştir. Ayrıca sorumluluk/uyumluluk özellikleri en fazla kadın ve beyaz yakalı olarak çalışan işgörenlerde görülmektedir. Alınan ücret arttıkça, işgörenlerin daha fazla dışadönük ve gelişime açık olduğu saptanmıştır. Ücret ve eğitim seviyesi düştükçe de nevrotizmin arttı̆̆1 tespit edilmiştir. Eğitim seviyesi ve ücreti yüksek, nispeten daha genç 26-35 yaş aralığındaki beyaz yakalı işgörenlerin iş tatminlerinin daha yüksek olduğu saptanmıştır.
\end{abstract}

Anahtar Kelimeler: Beş Faktör Kişilik Özellikleri, Depresyon, İş Tatmini 


\section{The Mediating Role Of Depression On The Impact Of Five Factors Of Personality On Job} Satisfaction

\section{Dr. Özge Turhan ${ }^{1 *}$}

First received: 03.05 .2019 Accepted: 22.06.2019

\section{Citation:}

IBAD Journal of Social Sciences

Issue: 5 Pages: 9-21

Year: 2019 Session: Fall

This article was checked by Turnitin. Similarity Index $21 \%$

${ }^{1}$ Turkey, ozge.turhan@yahoo.com. ORCID ID 0000-0001-5072-2712

\section{* Corresponding Author}

\begin{abstract}
The main purpose of this study is to identify the mediating role of depression in the interaction between five factors of personality and job satisfaction. According to the aim of the research, data was collected via survey method from 523 employees, 500 of them was appropriate and used in the analysis, who were working at diverse companies located in İstanbul, as a blue- and white-collar workers. In this respect, for data analysis, exploratory factor analysis, correlation and regression analysis were used, and significant results were obtained. According to the results; there was a significant positive correlation between depression and neuroticism, and also; depression has negative correlation with job satisfaction. Job satisfaction has positive correlation with extraversion, openess to experience and agreeableness/conscientiousness. Analysis indicates that depression has partial mediating role between five factors of personality and job satisfaction. As a result of conducted Anova and T-test analysis for demographic variables, it is determined that as the age and seniority increases, wages and level of education decreases as the depression has increased. As the level of education increased, it was determined that the employees showed more openess to experience and extraversion. And also; women and white-collar workers are more agreeableness/conscientiousness. As the wages increased, employees were found to be more extroverted and open to improvement. As the level of wages and education decreased, neuroticism increased. It was found that job satisfaction of white-collar workers with a higher education level and higher wages and younger than 26-35 age group was higher.
\end{abstract}

Keywords: Five Factor of Personality, Depression, Job Satisfaction 


\section{GİRIŞ}

Çağdaş yönetim yaklaşımlarının benimsenmesi rekabet, sürdürülebilirlik, kalite gibi kavramları doğurmuştur. İşletmeler etkin ve verimli olabilmenin bu kavramlarla yakından ilişkili olduğunun farkına varmıştır. Artan rekabetle baş edebilmenin, kalite standartları oluşturmanın ve bunları sürdürebilir kılmanın zorluğu örgütleri yine insana odaklatmıştır. İşgörenlerin teknik ve uzmanlık bilgisinin yanında duygularının da iş hayatında etkili olduğu anlaşılmıştır. Duygular insanın vazgeçilmez parçasıdır. Bireyin tutum ve davranışlarına yön veren en temel unsurdur. Araştırmalar; bireyin duygularını etkileyen en önemli ögenin kişilik olduğunu vurgulamaktadır. Kişilik bireyin ruh halini, duygu ve düşüncelerini, çevresini anlayışını hatta karar verme stillerini bile biçimlendiren faktördür.

Örgütler birçok farklı kişilik ve karakterin bir araya gelmesiyle oluşmaktadır. Beş faktör kişilik kuramına göre ise; bireylerin duygu, düşünce ve davranışlarını etkileyen özellikler mevcuttur. Bunlar beş farklı faktöre göre sınıflandırılmaktadır. Yani, bir kişilik sadece bir özellik barındırmamaktadır. Örgütler düşünüldüğünde birçok özelliği barındıran birçok farklı kişilik akla gelmektedir. $\mathrm{Bu}$ farklılıkları yönetebilmek, etkin ve verimli kılabilmek hem işgörenin hem de yöneticinin becerisi, bilgisinin yanında psikolojik durumundan da etkilenmektedir.

Kişilik farklılıkları, ruh halleri, işgörenlerin iş yapışlarına, performanslarına ve iş tatminlerine de yansımaktadır. Kimi kişilikler daha sosyal, içten ve yaptığı işten memnuniyet duyar iken, bazıları ise içe kapanık, pesimist, hiçbir şeyden memnun olmayan bireylerdir. Araştırmalar nevrotik kişilik özellikleri ağır basan bireylerin stresle kolay baş edemediğini, umutsuzluk, üzüntü, suçluluk ve depresyon gibi durumlara eğilimli olduklarını vurgulamaktadır.

İşgörenlerin ruh hallerinin ve yaşadıkları iş tatmininin, örgütlerin hedeflerine ulaşmasında etkisinin önemi göz önünde bulundurulunca, iş tatmini, depresyon ve her iki kavram açısından en temel faktör kabul edilen kişilik araştırmalara konu olmuştur. Beş faktör kişilik özelliklerinin iş tatmini üzerindeki etkisinde depresyonun rolü olabileceği varsayımılla bu etkileşimde depresyonun aracıllk rolü araştırılmaktadır. Çalışmada, kavramsal çerçeve üzerinde durulduktan sonra, sektör fark1 gözetmeksizin mavi ve beyaz yakalı işgörenlere yönelik araştırmaya yer verilmiş ve elde edilen bulgular yorumlanmaya çalışılmıştır.

\section{Kavramsal Çerçeve}

Çalışmanın bu kısımda araştırmaya konu olan kavramlar, alt boyutları ve birbirleriyle etkileşimleri açıklanmaktadır.

\subsection{Beş Faktör Kişilik Özellikleri}

McCrae ile Costa (1987) kişilik için, bireyin değişik koşullardaki davranışlarını açıklayan, devamlılık gösteren, bireylerarası duygusal, motivasyon ile deneyimsel etkileşim içeren bir süreç olduğunu vurgulamaktadır. Kişilik, kişilik özellikleri; üzerine çokça düşünülmüş bolca araştırma yapılmış bir konudur. Kişiliği temel olarak “dışadönük ve içedönük” biçiminde tanımlayan Jung'ın özellikler tipolojisi, Cattell'in kişilik özelliklerini sistematik bir biçimde tanımlaması ve kategorileştirmesi 16 faktörlü kişilik yapısını, Eysenck'in kişiliğin alt seviyelerindeki yapıları ortaya çıkarmak adına gerçekleştirdiği çalışması ve gerçekleştirilmiş birçok farklı çalışma kişiliğin beş kişilik özellikleri altında toplanabildiğini belirlemiştir. (Sığr1 ve Gürbüz, 2015, s.116-117) Beş faktör kişilik özellikleri, en yaygın şekilde kullanılan ve kabul görmüş sınıflamalardandır. Beş boyutlu, genel anlamda kişiliği açıkladığı varsayılan yapı; "dışadönüklük", "nörotiklik-nevrotizm", "gelişime açıklık", sorumluluközdisiplin" ve "uyumluluk" olarak adlandırılmıştır. "Uyumluluk"; güvenli, yumuşak başlı, açık sözlü, fedakâr, uyma davranışı ve alçakgönüllük gibi özellikleri barındıran boyuttur. "Nörotiklik-nevrotizm", uyum gösterme ve psikiyatrik kökenli problemlerle ilişkili olan boyuttur; depresyon, hassasiyet, sinirlilik, sevecenlik, içine kapanıklık gibi özellikler içeren bir boyut olduğu vurgulanmaktadır. Nevrotizm; bireyin deneyimlediği olaylarda sonuçlara ilişkin sürekli olumsuz sonuçlarla karşılaşacağı atfının yapılmasının yaygın görüldügü bir boyuttur. (Grant ve Wrzeniewski, 2010, s.108-121) Nevrotizm özelliği düşük seviyeli bireyler, duygular üzerinde iyi kontrol ve kararlılık sağlarken, yüksek seviyeli bireyler endişeye yatkınlık ile birlikte biraz hassas ve sinirli olabilirler. (Costa ve 
McCrae, 1992, s.5-13) Ayrıca, kişiliğin bu boyutundan yüksek puan alanlar psikiyatrik problem riski altında olabilir. (Rothmann ve Coetzer, 2003, s.68-74) "dlşadönüklük"; özelliği barındıran bireylerin coşkun, iddiac1, hareketli, heyecan arama eğilimli oldukları belirtilmektedir. Bir başka özellik ise "Sorumluluk-özdisiplin"dir. Sorumluluk boyutunun beş yaygın özelliğine vurgu yapılmaktadır. Bunlar; azim, hırs, başarma yönelimi, sistemli olma ve titizliktir. (Costa, McCrae ve David, 1991, s. 893) Sorumluluk; öğrenme ve sosyalleşmeye bağlı gelişen bir özelliktir. Sorumluluk özelliği bireylere düzenli olma, yeterlilik, başarma arzusu ve ihtiyatlı olma gibi özellikleri katmaktadır. Son özellik ise "gelişime açıklıktır." Bilişsel yönü en ağır basan bu özellik bireylere estetik görüş, hissiyat, hayal gücü yüksekliği, engin fikirler, değerler ve icraat yönelimli olma gibi özellikler katmaktadır.

\subsection{Depresyon}

Genel klinik tıpta depresif hastalık en yaygın psikiyatrik bozukluk olarak belirtilmektedir. (Kulaksızoğlu, Tükel, Üçok, Yargıç ve Yazıcı, 2009, s. 261) Hemen her toplumda yetişkinler arasında, yaşamlarının bir döneminde depresyon geçirme oranı yaklaşık \%20-25'tir. Depresyonun bu denli yaygın görülmesi, tüm toplumlarda ciddiyetinin farkına varılmasını sağlamıştır. Farkındalık sonucu bu rahatsızlık halk sağlığı problemi olarak tanımlanmıştır. (Güleç, 2014, s.32) Depresyon tanısı için DSM-5'te dokuz madde sıralanmıştır. Bunlar; günün büyük bir bölümünde çökkün duygudurum, etkinliklere karşı ilgide belirgin azalma ve/veya zevk almama (anhedoni), Aşırı kilo kaybı veya kiloda artış, uyku uyuyamama veya aşırı uyuma, ruhsal-devinsel kışkırma (ajitasyon) ya da tepkilerde yavaşlama, bitkinlik ya da içsel gücün kalmaması, değersiz hissetme ya da aşırı suçluluk duygusu, odaklanmakta güçlük çekme, yineleyici ölüm ya da kendini öldürme düşünceleridir. $\mathrm{Bu}$ dokuz belirtiden en az beşinin bulunması gerekir, iki haftalık dönem süresince devam da etmelidir. (Köroğlu, 2016, s.23) Depresyondaki bireylerde sıklıkla sağlık harcamalarında artış, işten uzaklaşma ve ölüm oranlarda artış tespit edilmiştir. Ayrıca yaşam kalitelerinin de ileri derecede bozulduğu vurgulanmaktadır. (Kulaksızoğlu ve diğerler, 2009, s.266)

\section{3. İş Tatmini (Doyumu)}

İş tatmini(doyumu); bireyin işine gösterdiği yaygın tutum olarak en basit şekilde tanımlanabilmektedir. Bireyin işine olan tutumu pozitif ya da negatif olabileceğine göre, bireyin çalışma hayatındaki deneyimleri sonucu ortaya çıkan olumlu ruh hali olarak tanımlamak, bireyin işi hakkındaki olumsuz tutumunu da iş tatminsizliği olarak adlandırmak yanlış olmayacaktır. (Erdoğan, 1999, s.231) Kavram, iki alt boyuttan oluşmaktadır. Bunlardan ilki içsel doyumdur. Bu boyut takdir edilme, başarı veya tanınma, sorumlu davranma ve terfiye bağlı görev değişikliği gibi işin içsel niteliğine ilişkin doyumu anlatmaktadır. İkinci boyut ise dışsal doyumdur. Örgütlerin geleceğe yönelik planları ve yönetim şekli, denetim mekanizmasının işleyiş biçimi, yöneticiler ve üstlerin astlarıyla ilişkisi, çalışma şartları, maaş-ücret gibi icra edilen işin çevresiyle ilişkili unsurları içeren doyumdur. (Aşkun Çelik ve Telman, 2013, s.160)

\section{4 İş Tatminine Beş Faktör Kişilik Özelliklerinin ve Depresyonun Etkisi}

Her işletme kuruluş aşamasında kendisine amaç ve hedefler belirlemektedir. Faaliyet gösterdiği sektör fark etmeksizin amaçlarına ulaşırken bunu kar elde edecek biçimde gerçekleştirmeyi arzulamaktadır. İşletmelerin hedeflerine ulaşmasında en temel faktör beşerî sermayesidir. Bu bilinçle örgütler işgörenlerinden yüksek performans beklemektedir. Araştırmalar yüksek performansın işgörenlerin psikolojik durumlarıyla, olumlu duygulanımla, iş tatminleriyle, örgüte olan bağlılıkları ve kurumlarının adil olup olmamasıyla ilişkili olduğunu tespit etmiştir. İş tatmininin işgörenin psikolojik durumundan etkileneceğini İnsan İlişkileri Yaklaşımı ve Hawthorne Araştırmaları kanıtlamıştır. İşgörenlerin psikolojik durumlarına etkisi olduğu bilinen faktörler arasında kişilik de yer almaktadır. Temel kişilik yapısına ek olarak, zaman, şartlar, mekân ve sosyal roller gibi faktörlerde bireylerin davranışlarını etkilemektedir. Bu bakımdan kişilerin davranış eğilimlerini şekillendiren temel kişilik özelliklerinin yanında becerileri, inançları, değerleri, tutumları arasında ayrım yapılmaktadır. Yani; kişiliğin oluşmasında, temel kişilik yapısına ek çevresel kişilik yapısı olarak farklılaşan ayrı bir yapı oluşmaktadır. Çevresel kişilik yapısı, ortamdan, çevreden ve yaşam olaylarından etkilenirken, kişilerin davranışlarının temel dayanağını oluşturan merkezi kişilik yapısı, ortamsal etkilerden, yaşam olaylarından ve çevresel faktörlerden çok fazla etkilenmemektedir. Beş faktör kişilik özellikleri 
düşünüldüğünde beş temel özellik, merkezi kişilik özelliği niteliğindedir. Beş faktör kişilik özelliklerinden uyumluluk boyutu düşünüldüğünde; uyumluluk özelliğine sahip kimselerin; yardımsever olduğu, çevrelerine saygılı ve kibar davranışlar sergilediği, arkadaş canlısı, cömert, güvenilir, yumuşak kalpli, hoşgörülü ve uzlaşmacı bireyler olduğu görülmektedir. (Bono, Boles, Judge ve Lauver, 2002, s.318) Uyumsuz bireylerin ise, kötümser, geçimi zor, uzlaşmacı olmayan, agresif, merhamet duygusundan yoksun, pragmatik bireyler olduğu vurgulanmaktadır. (Sevi, 2009, s.27) Sorumluluk boyutu, her şeye ihtiyatlı yaklaşmayı, süregelen işi yarım bırakmamayı ve bir işe girişmeden dikkatlice o iş hakkımda düşünme eğilimini ifade etmektedir. Ayrıca sorumluluk bilinci yüksek bireylerde, iş tatmini (doyum) ve motivasyonlarında da artış gözlemlenmektedir. (Somer, 1998, s.17-32) Kişiliğin nevrotizm-nevrotiklik alt boyutu; bireylere depresyona yatkınlık, içe kapanıklık ve sinirlilik gibi özellikler katmaktadır. Nevrotik kişilik özelliği yüksek bireyler de bu olumsuz özellikler görülmektedir. Bu tip kişilik özellikleri gösteren işgörenlerin depresyon yaşama olasılığı da yüksek olduğu saptanmıştır. Ayrıca Kendler et. al., (2006); Steunenberg ve ark., (2006); Cuijpers ve ark., (2007); Mustata and Gregory, (2009); Koorevaar et. al., (2013); Kardaş ve Şencan, (2018) depresyon ile kişilik özellikleri arasında ilişki olduğunu saptamıştır. O halde birey uyumsuz, sorumluluğu düşük ve nevrotizm özellikleri ağır basan bir işgören ise motive olabilir ve iş tatmini yaşayabilir mi? örgütüne yararlı olabilir mi? sorusunu akla getirmektedir. Bu sorudan yola çıkarak çalışmada kişilik özelliklerinin iş tatmini üzerindeki etkisinde depresyonun aracılık (mediator) rolünün tespitine yönelik araştırma gerçekleştirilmiştir.

\section{Yöntem}

Çalışmanın bu bölümünde araştırmaya ilişkin model, hipotezler ve örnekleme ait verilere yer verilmiştir.

\subsection{Araştırmanın Amacı ve Kapsamı}

$\mathrm{Bu}$ çalışmanın amacı beş faktör kişilik özelliklerinin iş tatmini üzerindeki etkisinde depresyonun aracilık rolünün tespit edilmesidir. Araştırma kapsam olarak, beş faktör kişilik özeliklerinin ve depresyonun iş tatminine etkisini ele almaktadır. İş tatminini etkilemesi muhtemel diğer faktörler göz ardı edilmiştir. Araştırmanın kısıtı ise, kişisel beyanı esas alarak gerçekleştirilmesidir.

\subsection{Araştırmanın Evreni ve Örneklemi}

Araştırmanın evrenini İstanbul'da farklı sektörlerde faaliyet gösteren işletmelerde görev alan mavi ve beyaz yakalı işgörenler oluşturmaktadır. Örneklem olarak kartopu yöntemiyle seçilmiş 523 beyaz ve mavi yakalı işgörene ulaşılmıştır. Cevaplanan anketlerden 23 adeti uç veriler içerdiğinden örneklem dışı bırakılmıştır. Değerlendirme 500 geçerli anket üzerinden yapılmıştır.

\subsection{Araştırmanın Modeli ve Hipotezleri}

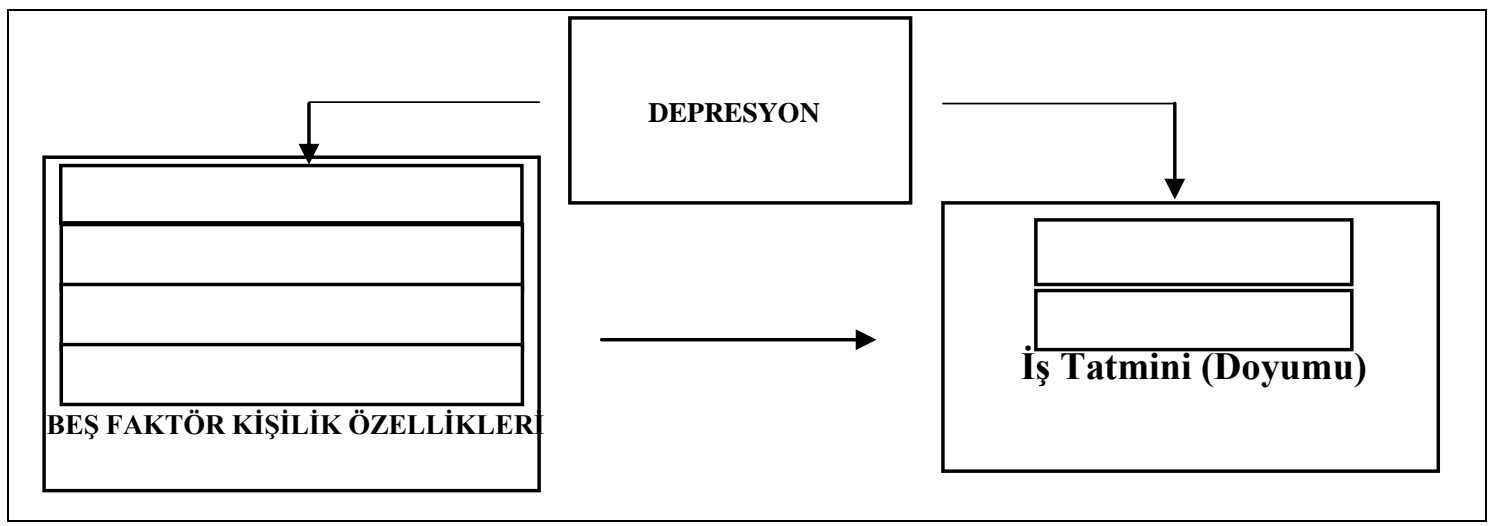

$\mathbf{H}_{\mathbf{1}}$ : Beş Faktör Kişilik özelliklerinin iş tatmini üzerindeki etkisinde depresyonun aracılık (mediator) rolü vardır.

$\mathbf{H}_{2}$ : Demografik özelliklere göre değişkenler farklılık göstermektedir. 


\subsection{Veri Toplama Araçları}

Araştırmada kullanılan veri toplama aracı iki bölüm olarak tasarlanmıştır. Birinci kısımda, demografik özelliklere yönelik 7 adet ifade bulunmaktadır. İşörenlerin; cinsiyet, yaş, eğitim düzeyi gibi kişisel verilerine yönelik ifadeler yer almaktadır. Anketin ikinci bölümünde depresyon ölçeğini içerin 21 ifade yer almaktadır. "Beck Depresyon Ölçeği toplam 21 ifadeden oluşmaktadır. Ölçek Beck ve ark. tarafından adolesan ve erişkinlerde depresyonun davranışsal bulgularını ölçmek amacıyla 1961 yılında geliştirilmiştir". (Beck, Ward ve Mendelson, 1961, s.561-571) Ölçekte dörtlü likert tipte olup, ifadeler kendini değerlendirme cümlelerinden oluşmaktadır. Bireyin kendisini değerlendirdiği bir ölçektir. Puan aralığı 0-63 arasında değiş̧ir. Türkiye için geçerlilik-güvenirlik çalışmaları Nesrin Hisli (Hisli, 1989, s.3-13), B. Tegin (Tegin, 1980) tarafından yapılmıştır. Çalışmanın ikinci ölçeği "Beş Faktör Kişilik Ölçeğidir. Bu ölçek; John, Donahue ve Kentle (John, Donahue ve Kentle, 1991) tarafından geliştirilmiş 44 adet ifade içermektedir". Beş faktörün prototipik bileşenlerini ölçmek için tasarlanmıştır. On ile sekiz ifade arasında değişen alt ölçekleri içermektedir. İyi psikometrik özellikleri barındırması ve alt ölçekleri iyi temsil eden ifadeleri içermesi ölçeğin güçlü yönlerindendir. (John ve Srivastava, 1999, s.102-138) Ölçek "Dışadönüklük" alt boyutuna yönelik 8 ifade, "Uyumluluk/yumuşak başl1lık" alt boyutuna yönelik 9, "Öz disiplin/sorumluluk" alt boyutuna ait 9 ifade, "Nevrotizm (duygusal dengesizlik)" alt boyutuna yönelik 8 ifade ve son alt boyut olan "Deneyime Açıklık" boyutuna yönelik 10 ifade içermektedir. Beşli likert tipli bir ölçektir. Ölçekteki 2., 6., 8., 9., 12., 18., 21., 23., 24., 27., 31., 34., 37., 41. ve 43. ifadeler tersten (reverse) puanlanmaktadır. (John ve Srivastava, 1999, s.102-138) Ölçeğin Türkçe uyarlaması Sümer ve Sümer (Sümer ve Sümer, 2005) tarafından yapılmıştır. Çalışmanın son ölçeği ise "Minesota İş Tatmin (doyum) ölçeğidir. Ölçek Weiss ve arkadaşları tarafından 1967 yılında geliştirilmiştir". (Weiss, Dawis, England ve Lofquist, 1967) 20 adet ifade ve iki adet alt boyut içermektedir. Ölçeğin Türkçe uyarlaması Özdayı (Özdayı, 1991, s.237-251) tarafından yapılmıştır.

Ölçeklerin güvenilirliğinin sınanmasına yönelik Cronbach Alpha analizi ve yapı geçerliliğinin sınanmasına yönelik doğrulayıcı faktör analizleri temel bileşenler yöntemi ve varimax döndürme yöntemi kullanılarak gerçekleştirilmiştir. Veri setinin faktör analizine uygunluğu için "Kaiser-MeyerOlkin" (KMO) örneklem yeterliliği testi ve "Barlett Küresellik Testi" uygulanmıştır.

Beck Depresyon Ölçeğinin $\left[\mathrm{KMO}=.892 ; \mathrm{X}^{2}(210)=5651.765, \mathrm{p}<0.001\right]$. Veri grubu için yapilan Bartlett Küresellik testi sonucu $\mathrm{p}<0,001$ bulunduğundan, ölçeğin ifadeleri arasında anlamlı bir ilişki olduğu anlaşılmaktadır. KMO uygunluk testi sonrası, gerçekleştirilen faktör analizi sonucunda Beck depresyon ölçeğinin kümülatif varyansının 66,587 olduğu tespit edilmiştir. Cronbach's Alpha değerinin 0,70 ve üstü olduğu durumlarda ölçek güvenilir olarak kabul edilir. Çalışmamızda ölçeğin değeri .902 olduğundan ölçeğin güvenilir olduğu saptanmıştır.

Beş Faktör Kişilik özellikleri ölçeğinin faktör analizine uygunluğu için, gerçekleştirilen KMO test sonucu $\left[\mathrm{KMO}=.859 ; \mathrm{X}^{2}(105)=3724.885, \mathrm{p}<0,001\right]$ hesaplanmıştır. Faktör analizi sonucu toplam varyansın 69,336 olduğu ve 4 alt boyuttan oluştuğu saptanmıştır. Cronbach Alfa değerlerinin dışadönüklük .859 , nevrotizm .841 , gelişime açıklık .751 ve sorumluluk/uyumluluk için .606 olduğu saptanmıştır. Ölçeğin güvenilir olduğu elde edilen değerler vasıtasıyla kanıtlanmıştır.

İş Tatmini ölçeğine uygulanan Kaiser Meyer Olkin $(\mathrm{KMO})$ test sonucu [KMO=.847; $\mathrm{X}^{2}(36)=$ 2681.397, $p<0,001]$ hesaplanmıştır. KMO uygunluk testi sonrası, gerçekleştirilen faktör analizi sonucu toplam varyansın 68,841 olduğu saptanmıştır. İki alt boyut ile temsil edildiği tespit edilmiştir. Ölçeğin Cronbach Alfa değerinin .878 olduğu saptanmıştır. Bu sonuç ölçeğin güvenilir olduğunu göstermektedir. Analiz sonuçları, ankette kullanılan üç ölçeğin de geçerli ve güvenilir olduğunu göstermektedir.

\section{Bulgular}

“Araştırmada depresyonun aracı (mediating) etkisi, Baron ve Kenny'nin modeline ilişkin basamaklara dayalı bir dizi hiyerarşik çoklu regresyon analizi ile gerçekleştirilmiştir. Her bir alt boyut için normallik testi uygulanıp, "çarpıklık ve basıklık değerlerinin +2 ve -2" (George ve Mallery, 2010) referans değerlerinin arasında olduğu sonucuna ulaşılmıştır. Depresyon $[.238, .246]$, gelişime açıklık 
[.094, -713], dişadönüklük [-334, -1.207], nevrotizm [-.206, -1.096], sorumluluk/uyumluluk [.335, $.541]$, içsel doyum [.650, -.628], dişsal doyum [-1.082, .643] değerleri saptanmıştır. Normal dağılım eğilimi gösterdiği kabul edilip parametrik testler uygulanmıştır. Analizlerde, olası çoklu doğrusallık (multicollinearity) sorununu azaltmak maksadıyla standart z-puanlar kullanılmıştı’" (Baron ve Kenny, 1986, s.1173-1182).

Araştırmaya katılan işgörenlerin demografik özellikleri incelendiğinde, \% 53'ünün Kadın, \% 47'sinin Erkek olduğu, \%42'lik oranla en fazla $26-35$ yaş arasındaki işgörenlerin temsil edildiği, bu oran1 \%29 ile 36-45 yaşın izlediği görülmektedir. Katılımcılardan \%62'sinin evli olduğu, \%65 ile en fazla üniversite mezunu işgörenin temsil edildiği, bunu \% 25'lik oranla lise mezunları izlemektedir. Mavi yakalı işgörenler \% 36, beyaz yakalılar ise \% 64 oranındadır. Katılımcıların \% 51 ile en fazla 5.000TL ve altı ücrete çalıştığ 1 , \% 2'lik oranla da $12.500 \mathrm{TL}$ ve üstü ücret alan işgörenin en az temsil edildiğini görmekteyiz. İşgörenlerin kıdemleri incelendiğinde \% 33 oran ile 15+ y1l kıdemli işgörenlerin en fazla temsil edildiği, en az da \% 16 ile 10-15 yıl kıdemli işgörenlerin temsil edildiği tespit edilmiştir.

\subsection{Korelasyon Analizine İlişskin Bulgular}

Tablo 1. Betimleyici İstatistikler ve Korelasyonlar

\begin{tabular}{|l|c|c|c|c|c|c|c|c|c|c|}
\hline DEĞİŞKENLER & ORT. & SS & $\mathbf{1}$ & $\mathbf{2}$ & $\mathbf{3}$ & $\mathbf{4}$ & $\mathbf{5}$ & $\mathbf{6}$ & $\mathbf{7}$ & $\mathbf{8}$ \\
\hline 1. Depresyon & .7750 & .415 & 1 & & & & & & & \\
\hline 2. Gelişime Açıklık & 2.85 & .897 & $-.518^{* *}$ & 1 & & & & & & \\
\hline 3. Dışadönüklük & 3.10 & .980 & $-.423^{* *}$ & $.467^{* *}$ & 1 & & & & & \\
\hline 4. Nevrotizm & 3.40 & .958 & $.639^{* *}$ & $-.444^{* *}$ & $-.444^{* *}$ & 1 & & & & \\
\hline $\begin{array}{l}\text { 5. Sorumluluk- } \\
\text { Uyumluluk }\end{array}$ & 2.91 & .922 & $-.520^{* *}$ & $.387^{* *}$ & $.465^{* *}$ & $-.362^{* *}$ & 1 & & & \\
\hline 6. İçsel Doyum & 2.64 & .924 & $-.688^{* *}$ & $.654^{* *}$ & $.492^{* *}$ & $-.648^{* *}$ & $.514^{* *}$ & 1 & & \\
\hline 7. Dişsal Doyum & 3.53 & .732 & $-.552^{* *}$ & $.352^{* *}$ & $.357^{* *}$ & $-.494 * *$ & $.436^{* *}$ & $.491^{* *}$ & 1 & \\
\hline 8. Genel Doyum & 3.04 & .730 & $-.729^{* *}$ & $.617^{* *}$ & $.505^{* *}$ & $-.676^{* *}$ & $.555^{* *}$ & $.922^{* *}$ & $.790^{* *}$ & 1 \\
\hline
\end{tabular}

Depresyon, beş faktör kişilik özellikleri ve iş tatmininin alt boyutlarının birbirleriyle ilişkisinin tespitine yönelik gerçekleştirilen korelasyon analizi sonucu, depresyonun sadece nevrotizm ile pozitif yönlü anlamlı ilişkisi olduğu diğer bütün alt boyutlarla da negatif yönlü anlamlı ilişkisi olduğu tespit edilmiştir. İş tatmininin iki alt boyutunun beş faktör kişilik özellikleriyle ilişkisi incelendiğinde; nevrotizm ile negatif, gelişime açıklık, dışadönüklük, sorumluluk/uyumluluk alt boyutlarıyla ise pozitif yönlü anlamlı ilişkisi olduğu tespit edilmiştir. Özetle; depresyon ile nevrotizm arasında pozitif yönlü anlamlı ilişki olduğu, diğer alt boyutların her biri ile negatif yönlü, anlamlı ilişkisi olduğu saptanmıştır.

\subsection{Beş Faktör Kişilik Özelliklerinin İş Tatmini Üzerindeki Etkisinde Depresyonun Aracılık Etkisi}

Araştırmanın kapsamında depresyonun aracılık rolünü saptamak adına Baron ve Kenny (1986) modeli olarak adlandırılan hiyerarşik çoklu regresyon modeli kullanılmıștır. Model, aracılık rolünün tespitine yönelik dört koşul içermektedir. Bu koşullar sağlandığında aracılık etkisinin saptandığından bahsedilebilmektedir. İlk olarak, yordayıcı değişken (beş faktör kişilik özellikleri) ile aracı değişken (depresyon) arasında anlamlı ilişkinin saptanmış olması gereklidir. İkinci olarak yordayıcı değişken ile yordanan değişken arasında (İş Tatmini) anlamlı ilişkinin tespit edilmiş olması şarttır. Üçüncü şart, aracı değişken ile yordanan değiş̧ken arasında anlamlı ilişkinin saptanmasıdır. Son şart olarak da, aracı değişken kontrol edildikten sonra yordayıcı ve yordanan değişken arasındaki ilişki anlamlı olarak azalmalıdır. Buna göre, araştırmanın birinci hipotezinin doğruluğunun sınanması için aracılık testi ugulanmıştır. Analize yönelik bulgular; tablo 2'de yer almaktadır. 
Beş Faktör Kişilik Özelliklerinin İş Tatmini Üzerindeki Etkisinde Depresyonun Aracılık Rolü

Tablo 2: Regresyon Analizi Depresyon Arac1l1k Modeli

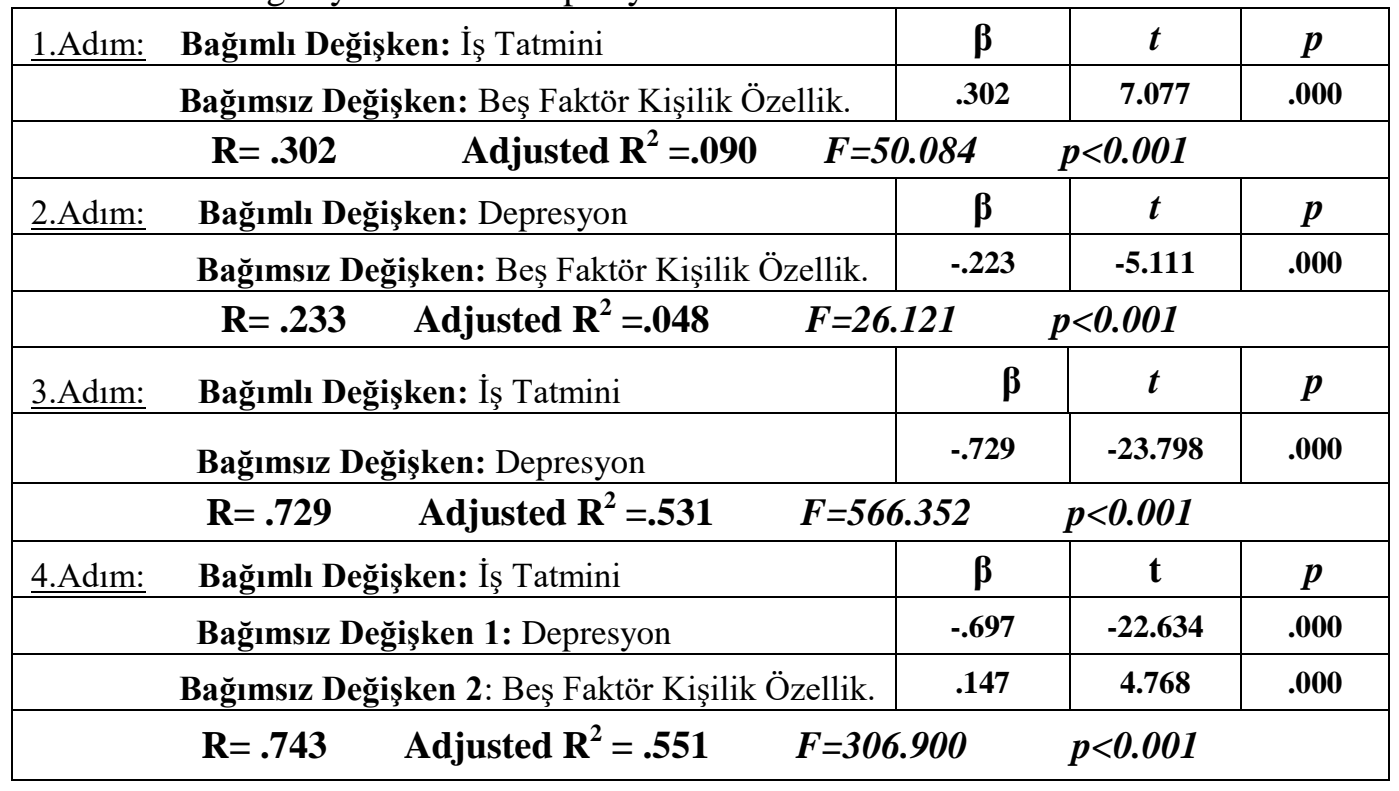

Depresyonun aracılık etkisine yönelik gerçekleştirilen regresyon analizi sonuçlarına göre; ilk adımda iş tatmininin beş faktör kişilik özellikleri üzerine pozitif yönlü ve anlamlı etkisinin $(\boldsymbol{\beta}=\mathbf{0 . 3 0 2}, \mathbf{p}<\mathbf{0 . 0 5})$ olduğu, ikinci adımda depresyonun beş faktör kişilik özellikleri üzerinde negatif yönlü anlamlı etkisinin $(\boldsymbol{\beta}=-\mathbf{. 2 2 3}, \boldsymbol{p}<\mathbf{0 . 0 5})$ olduğu tespit edilmiştir. Üçüncü adımda iş tatmininin depresyon üzerine negatif yönlü $(\boldsymbol{\beta}=\mathbf{- . 7 2 9}, \mathbf{p}<\mathbf{0 . 0 5})$ anlamlı etkisinin olduğu saptanmıştır. Son adımda aracı değişken modele eklendiğinde bağımlı değişken üzerindeki etkisi $(\boldsymbol{\beta}=\mathbf{0 . 3 0 2})$ değerinden $(\boldsymbol{\beta}=\mathbf{0 . 1 4 7})$ değerine azalarak istatistiksel olarak anlamlı etkisini yitirmiştir. Bu bulgular beş faktör kişilik özellikleri ile iş tatmini arasındaki ilişkide depresyonun aracılık rolü olduğunu göstermiştir. Yani beş faktör kişilik özelliklerinin iş tatmini yaşama olasılığını arttırdığını, yaşanan depresyonun iş tatminini azalttı̆̆ 1 ve aynı zamanda beş faktör kişilik özellikleri göstermeyi de negatif etkilediği doğrulanmıştır. Özetle; Tablo 2 aracıllı̆̆ıla paylaşılan veriler değerlendirildiğinde $\boldsymbol{\beta}$ değerinin $\mathbf{. 3 0 2}$ den aracı değişkenin modele dahil edilmesiyle $\boldsymbol{\beta}$ 'nın değerinin azalarak .147 değerini aldığını ancak tamamen ortadan kalkmadığını $(\mathbf{p}<\mathbf{0 . 0 0 1})$ tam aracılık tespit edilmese de "kısmi aracılık etkisi vardır" kabul edilmiştir. Hesaplanan $\boldsymbol{\beta}$ değerindeki düşüşün anlamlı olup olmadığının tespitine yönelik Sobel testi gerçekleştirilmiştir. "Sobel testi, aracılık rolünde bağımsız değişken tarafından açılanan varyanstaki azalmanın anlamlılığını test edebilmek için kullanılan istatistiksel bir hesaplama biçimidir". (Sobel, 1982, s.290-312) Uygulanan analiz sonucu; depresyonun Sobel $\mathbf{z}=\mathbf{5 . 0 4}, \mathbf{p}=\mathbf{0 . 0 0 0}$ elde edilmiş olup, aracılık etkisinin anlamlı olduğu saptanmıştır. Aracılığa yönelik varsayılan $\mathbf{H}_{1}$ hipotezi kısmi aracılık rolü saptandığından kabul edilmiştir.

Araştırmanın son hipotezi olan demografik özelliklerin farklılaşıp farklılaşmadığına yönelik fark testleri ( $t$-test ve Anova) gerçekleştirilmiştir. Analizler vasıtasıyla elde edilen sonuçlara göre; "T-testi yorumlanırken anlamsız çıkan değerler için (equal variances assumed) ilk satır, anlamlı çıkması durumunda bir alt satırdaki (equal variances not assumed), (Sig). anlamlılık değerlerine bakılarak yorumlama yapılmıştır”. (Gürbüz ve Şahin, 2016, s.237)

Araştırmaya katılan gönüllülerin "cinsiyetlerine" göre yapılan t-testi analizi sonuçlarına göre, cinsiyet ile sorumluluk/uyumluluk alt boyutunda farkl1lık tespit edilmiştir. [ $\mathrm{t}(500)=3.937, \mathrm{p}=.000]$ Cinsiyete göre, depresyon, gelişime açıklık, dışadönüklük, nevrotizm, içsel ve dişsal doyum farklılık göstermemektedir. Farklılık gösteren sorumluluk/uyumluluk kadın işgörenler tarafından sahip olunan bir özelliktir. ( $\bar{X}: 3.07$ SS: .957). Medeni duruma göre hiçbir alt boyut farklılık göstermemiştir. Çalışlan pozisyona göre farklılık tespit edilmiştir. Farklılık sorumluluk/uyumluluk [t $(500)=2.805$, $\mathrm{p}=.004]$ boyutunda, iş tatmininin içsel doyum boyutunda [ $\mathrm{t}(500)=-2.249, \mathrm{p}=.031]$ ve dişsal doyum [ $\mathrm{t}$ $(500)=-6.693, p=.000]$ boyutunda saptanmıştır. Ortalamalara göre, içsel ( $\bar{X}: 2.88$ SS: .944). ve dışsal doyum ( $\bar{X}: 3.58$ SS: .689) beyaz yakalılarda daha fazla yaşanmaktadır. Yani; iş tatmini beyaz 
yakalılarda daha yüksektir. Sorumluluk/uyumluluk da beyaz yakalılarda daha fazladır. ( $\bar{X}: 3.00$ SS: .945). Tek yönlü varyans analizi (Anova) ve çoklu karşılaştırma testleri (post-hoc) (Tukey, Scheffe ve Tamhane) Anova analizlerinde homojenlik sağlanamayan koşullarda "Welch ve Brown-Forsythe testleri" kullanılarak farklılık analizleri gerçekleştirilmiştir. Yaş ile depresyon $\left[\mathbf{F}_{4,495}=5,761, \mathrm{p}=.000\right]$ ve içsel doyum $\left[\mathbf{F}_{4,495}=4,283, \mathrm{p}=.002\right]$ arasında fark saptanmıştır. Yaş ilerledikçe yaşanan

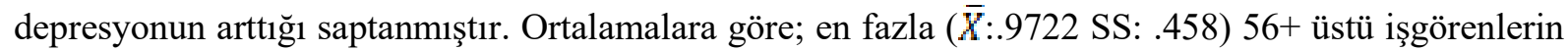
depresyon yaşadığ işgörenler tarafından yaşandığı saptanmıştır. Kıdem ile depresyon $\left[\mathbf{F}_{4,495}=5.761, p=.000\right]$, gelişime aç1kl1k $\left[\mathbf{F}_{4,495}=1.748, \mathrm{p}=.138\right]$, sorumluluk/uyumluluk $\left[\mathbf{F}_{4,495}=1.740, \mathrm{p}=.140\right]$ ve içsel doyum $\left[\mathbf{F}_{4,495}=\right.$ 4.283, $\mathrm{p}=.002]$ alt boyutları arasında fark tespit edilmiştir. Ortalamalar incelendiğinde; kıdemi $15+\mathrm{y} 11$ $(\bar{X}: 8830$ SS: .426) olan işgörenlerin en fazla depresyon yaşadığı, gelişime açıklık ( $\bar{X}: 2.93$ SS: .912) özelliğine sahip olduğu, sorumluluk/uyumluluk özelliğine ise 10-15 y1l kıdemi olan ( $\bar{X}: 3.29$ SS: .930) içsel doyum en fazla yaşayan işgörenlerin ise 10-15 yıl kıdeme ( $\bar{X}: 2.67 \mathrm{SS}: .854)$ sahip olanlar olduğu tespit edilmiştir. Eğitim durumuna göre farklılık tespit edilmiştir. Ortalamalara göre; depresyon $\left[\mathbf{F}_{3,496}=28.197, \mathrm{p}=.000\right]$ en fazla lise mezunlarının ( $\left.\bar{X}: .9935 \mathrm{SS}: .380\right)$ yaşadığ 1 ve eğitim durumu yükseldikçe azaldığı saptanmıştır. Gelişime açıklık $\left[\mathbf{F}_{3,496}=22.039, \mathrm{p}=.000\right]$, dışadönüklük $\left[\mathbf{F}_{3,496}=\right.$ 7.527, $\mathrm{p}=.000]$, nevrotizm $\left[\mathbf{F}_{3,496}=9.130, \mathrm{p}=.000\right]$, sorumluluk/uyumluluk [ $\left.\mathbf{F}_{3,496}=11.031, \mathrm{p}=.000\right]$, içsel doyum $\left[\mathbf{F}_{3,496}=31.410, \mathrm{p}=.000\right]$, dişsal doyum $\left[\mathbf{F}_{3,496}=5.097, \mathrm{p}=.002\right]$ ile de farklılık tespit edilmiştir. Ortalamalar incelendiğinde; eğitim seviyesinin yükseldikçe yaşanan iş tatmininin arttığ1, içsel ( $\bar{X}: 4.10 \mathrm{SS}: .707)$ ve dışsal doyum $(\overline{\bar{X}}: 3.77 \mathrm{SS}: .660)$ alt boyutunda, eğitim seviyesi arttıça işgörenlerin gelişime açık ( $\bar{X}: 8830 \mathrm{SS}: .426)$, dişadönük ( $\bar{X}: 3.67 \mathrm{SS}: .807)$, sorumluluk/uyumluluk $(\bar{X}: 3.52$ SS: .998$)$ özellikleri gösterdikleri de tespit edilmiştir. İşgörenlerin eğitim seviyesinin düşmesinin ise nevrotizm $(\bar{X}: 3.70$ SS: .879) özellikleri sergilemelerini arttırdığı tespit edilmiştir. Gerçekleştirilen anova testine göre, ücret ile depresyon $\left[\mathbf{F}_{4,495}=5.043, \mathrm{p}=.001\right]$, gelişime açıklık $\left[\mathbf{F}_{4,495}=16.556, \mathrm{p}=.000\right]$, dişadönüklük [ $\left.\mathbf{F}_{4,495}=16.556, \mathrm{p}=.001\right]$, nevrotizm [ $\left.\mathbf{F}_{4,495}=8.247, \mathrm{p}=.000\right]$, içsel doyum $\left[\mathbf{F}_{4,495}=23.671, \mathrm{p}=.000\right]$, dişsal doyum $\left[\mathbf{F}_{4,495}=5.038, \mathrm{p}=.001\right]$ arasında fark tespit edilmiştir. Ortalamalar incelendiğinde; ücret düştükçe 5.000TL ve altı ( $\bar{X}: .8534$ SS: .404) depresyon artmaktadır. Ayrıca nevrotizm özellikleri de 5.000TL ve altı ( $\bar{X}: 3.61 \mathrm{SS}: .916)$ ücret alan işgörenlerde artmaktadır. Gelişime açıklık 12.501TL ve üstü ( $\bar{X}: 4.25 \mathrm{SS}: .707)$, dişadönüklük 12.501TL ve üstü $(\bar{X}: 4.15$ SS: .265) ücret arttıkça artmaktadır. İçsel doyum 12.501 TL ve üstü ( $\bar{X}: 4.00$ SS: .828) ve dışsal doyum 12.501TL ve üstü ( $\bar{X}: 4.15$ SS: .533) ücret alan işgörenlerde daha fazladır.

\section{Tartışma}

Gerçekleştirilen analizler sonucu; kişiliğin iş tatmini ile arasında anlamlı ilişki olduğu saptanmıştır. Literatür incelendiğinde benzer sonuçlara ulaşmış araştırmaların olduğu görülmektedir. Kardaş ve Şencan; kişiliğin özelliklerinden dışadönüklük, duygusal denge, yeniliğe açıklık, sorumluluk ve uyumluluk ile iş tatmini (doyumu) arasında anlamlı ilişki olduğunu tespit etmişlerdir. (Kardaş ve Şencan, 2018, s.297) Doğar; bankacılık sektöründe gerçekleştirdiği araştırmasında sosyal, uzlaşmacı tavır sergileyen ve öğrenmeye açık olan işgörenlerin iş tatminlerinin de daha fazla olduğunu tespit etmiştir. (Doğar, 2016, s.1244) Judge, Heller ve Mount; gerçekleştirdikleri meta-analiz sonucu, nevrotizm ve dışadönüklük alt boyutlarının yaygın olarak iş tatminiyle ilişkisi olduğunu tespit etmişlerdir. Ayrıca nevrotizmin bu ilişkide negatif etkisi olduğunu ve etkisi en önemli değişken olduğunu saptamışlardır. (Judge, Heller ve Mount, 2002, s. 533) Bu çalışmada da nevrotizmin iş tatmini ile negatif ilişkisi saptanmıştır. Gerçekleştirilen fark analizleri ayrıca eğitim seviyesi ve ücreti yüksek, nispeten daha genç 26-35 yaş aralığındaki beyaz yakalı işgörenlerin iş tatminlerinin daha yüksek olduğunu göstermiştir. Benzer sonucu Çarıkçı; çalışmasında tespit etmiştir. Cinsiyet, eğitim, yaş faktörlerinin iş tatminini etkilediğini saptamıştır. Erkeklerin ve genç işgörenlerin iş tatminlerinin daha yüksek olduğunu tespit etmiştir. (Çarıkçı, 2000, s. 155-168) Bu çalışmada depresyonun cinsiyete göre farklılık göstermediği tespit edilmiştir. Farklı örneklem grubunda araştırmanın gerçekleştirilmiş olması bu sonucun saptanmasına sebep olabilmiştir yorumunu getirebiliriz. Literatür incelendiğinde iş tatminini kişiliğin dışında başka faktörlerinde etkileyebileceği vurgulanmaktadır. Yılmaz ve Dönmez; çalışmalarında eğitim düzeyinin, cinsiyetin, benlik saygısının ve depresyonun iş tatminini yordayan 
değişkenler olduğunu saptamışlardır. Ayrıca alınan eğitim ile uyumlu işlerde çalışan işgörenlerin iş tatminlerinin de daha yüksek olduğunu tespit etmişlerdir. (Yılmaz ve Dönmez, 2013, s.91) Ilgaz Yıldırım, Gülmez ve Yıldırım; iş tatmininin gelişime açıklık ve sorumluluk alt boyutlarıyla ilgili olduğunu saptamışlardır. (Ilgaz Yıldırım, Gülmez ve Yıldırım, 2016, s.284-291) Ayrıca evli işgörenlerin iş tatminlerinin daha yüksek olduğunu tespit etmişlerdir. Bu çalışma medeni durum hiçbir alt boyutla farklılık göstermemiştir. Gerçekleştirilmiş çalışmalardan yola çıkarak kişiliğin iş tatmini üzerindeki etkisinde depresyonun aracılığının tespitine yönelik gerçekleştirilen bu çalışmada depresyonun kısmi aracılık etkisi saptanmıştır. Literatürde benzer bir çalışmaya ulaşılamadığından karşılaştırılması gerçekleştirilememiştir. Çeler; depresyon ile iş tatmini arasında negatif korelasyon olduğunu tespit etmiştir. Çalışma süresi, cinsiyet ve medeni duruma göre depresyon görülme oranının da farklılaşmadığını saptamışıtır. (Çeler, 2015, s.130-133) Depresyon üzerine gerçekleştirilmiş gerek ulusal gerekse uluslararası araştırmalar mevcuttur. Llyod, Streiner ve Shannon; çalışmalarında depresyonun iş tatminini düşürdügünü saptamışlardır. Ayrıca yıllık tatil gün sayısı düştükçe de depresyon yaşama olasılığını arttırdığını tespit etmişlerdir. (Llyod, Streiner ve Shannon, 1994, s.562) Hagan ve Kay; kadın avukatlarda depresyonun iş tatminini düşürdügünü tespit etmişlerdir. (Hagan ve Kay, 2007, s.51-78) Ferguson, Frost ve Hal; çalışmalarında stres ve depresyonun iş tatminini negatif etkilediğini saptamışlardır. (Ferguson, Frost ve Hall, 2012, s. 27-41) Goovardhan, Pinelli ve Schnatz; tükenmişlik yaşayan işgörenlerin işlerinden daha az tatmin olduklarını ve depresyon yaşama oranlarının da daha yüksek olduğunu tespit etmişlerdir. (Goovardhan, Pinelli ve Schnatz, 2012, s.389395) Depresyonun kişilikle ilişkisini inceleyen araştırmalar aralarında anlamlı ilişki olduğunu saptamıştır. Kişiliğin nevrotizm-nevrotiklik alt boyutu; bireylere depresyona yatkınlık, içe kapanıklık ve sinirlilik gibi özellikler katmaktadır. Nevrotik kişilik özelliği yüksek bireyler de bu olumsuz özellikler görülmektedir. Bu tip kişilik özellikleri gösteren işgörenlerin depresyon yaşama olasılığı da yüksek olduğu saptanmıştır. Tıpkı bu çalışmada tespit edildiği gibi. Ayrıca Kendler et. al., (2006); Steunenberg ve arkadaşları, (2006); Cuijpers et. al., (2007); Mustata and Gregory, (2009); Koorevaar ve ark., (2013); depresyon ile kişilik özellikleri arasında ilişki olduğunu saptamıştır. Depresyon üzerine gerçekleştirilmiş çalışmaların kısıtlı ve benzer örneklem grupları üzerinde gerçekleştirildiği görülmektedir. Çalışmamın farklı örneklem grubu üzerinde gerçekleştirilmesi önem arz etmektedir. Örgütsel davranış alanına yeni bulgular sağlaması amacı ile bu araştırma gerçekleştirilmiştir.

\section{Sonuç ve Öneriler}

Gerçekleştirilen analizler sonucunda; beş faktör kişilik özelliklerinin iş tatmini üzerindeki etkisinde depresyonun kısmi aracılık rolü olduğu tespit edilmiştir. Yani; kişilik özelliklerinin olumsuz yanlarının baskın olduğu bireylerde depresyonun yüksek olduğu ve yaşanan depresyona bağlı iş tatmininin düştüğü saptanmıştır. Ayrıca korelasyon analizi sonuçları; depresyonun beş faktör kişilik özelliklerinden nevrotizm ile pozitif yönlü anlamlı ilişkisi olduğunu kanıtlamaktadır. Depresyonun iş tatmininin her iki alt boyutuyla negatif, beş faktör kişilik özelliklerinden dişadönüklük, gelişime açıklık, sorumluluk/uyumluluk ile pozitif yönlü, anlamlı ilişkisi olduğu saptanmıştır. Fark testleri sonuçlarına göre; yaş ilerledikçe, kıdem arttıkça, ücret ve eğitim seviyesi düştükçe depresyon yaşama olasılığı artmaktadır. Beyaz yakalılarda ve kadınlarda sorumluluk/uyumluluk özellikleri daha fazladır. Eğitim seviyesi arttıkça işgörenlerin gelişe açık, dışadönük, sorumluluk/uyumluluk daha fazla gösterdikleri tespit edilmiştir. Ücret arttıkça da işgörenlerin daha fazla dışadönük, gelişime açık olduğu saptanmıştır. Ücret ve eğitim seviyesi düştükçe de nevrotizmin arttığı tespit edilmiştir. Eğitim seviyesi ve ücreti yüksek, nispeten daha genç 26-35 yaş aralığındaki beyaz yakalı işgörenlerin iş tatminlerinin daha yüksek olduğu saptanmıştır.

Sonuç olarak; kişiliğin olumsuz özellikler barındırabileceği ve bu olumsuz özelliklerin arttığı bireylerde yaygın olarak depresyon olabileceği ve bunun iş tatminlerine olumsuz yansıyacağı tespit edilmiştir. Bu olumsuzlukların örgüte negatif etkisi olabileceği de bilinmektedir. Bulgular, olumsuzluklarla nasıl baş edilebilir sorusuna akla getirmektedir. Depresyonun olumsuz etkilerini en aza indirebilmek ya da ortadan kaldırabilmek için örgütler çeşitli mücadele yöntemleri geliştirebilmelidir. Bunların başında depresyonun tedavi edilebilir bir rahatsızlık olduğu unutulmamalıdır. İlaç ve psikoterapi yaygın tedavi biçimidir. Ayrıca kişiliğin de geliştirilebilir bir kavram olduğu bilinmektedir. İşgörenlerin olumsuz yanlarının farkına varması sağlanıp, yeni tutum ve davranışlar edinmesi teşvik edilebilir. Ayrıca; örgütler özellikle mavi yakalılarda iş tatminini arttırmak 
için rotasyon, iş zenginleştirme ve basitleştirme yöntemleri kullanabilir. Başka bir öneri olarak da; örgüt kültürünü yansıtan ortak değerlerin tespit edilip, bu değerlerin işgörenler tarafından benimsenmesinin sağlanması gösterilebilir. Böylece işgörenlerin tutum ve davranışlarına ortak değerlerin yön vermesi sağlanmış olup, işlerine karşı olumlu tutum ve davranış göstermeleri pekiştirilmiş olacaktır.

\section{KAYNAKÇA}

Aslan Y1lmaz, H. ve Dönmez, A. (2013). İş doyumunu tayin eden bazı psikolojik ve demografik değişkenler. Türk Psikoloji Yazılarl, 16(3), 91-97.

Aşkun Çelik, D., ve Telman, N. (2013). Endüstri/örgüt psikolojisi alanında kullanılan ölçekler el kitabl. Ankara: Nobel Akademik Yayınc1lık.

Baron, R.M., ve Kenny, D.A. (1986). The moderator-mediator variable distinction in social psychological research: Conceptual, strategic, and statistical considerations. Journal of Personality and Social Psychology, 51(6), 1173- 1182.

Beck, A. T., Ward, C., and Mendelson, M. (1961). Beck depression inventory (BDI). Arch Gen Psychiatry, 4(6), 561-571.

Bono, J.E., Boles, T.L., Judge, T.A. and Lauver, K.J. (2002). the role of personality in task and relationship conflict. Journal of Personality. 70(3), 1311-1344.

Costa, P.T., ve McCrae, R.R. (1992). Normal personality assessment in clinical practice the NEO personality inventory. Psychological Assessment, 4(1), 5-13.

Costa, P.T., McCrae, R.R., ve David, A. D. (1991). Facet scales for agreeableness and conscientiousness: A revision of the neo personality inventory. Personality an Individual Differences, 12(9), 887-898.

Cuijpers ve ark. (2007). Actions taken to cope with depressed mood: The role of personality traits. Aging \& Mental Health, 11(4), 457-463.

Çarıkçı, İ. (2000). Çalışanların iş tatminlerini etkileyen kişisel özellikler- Süpermarket çalışanları üzerinde bir araştırma-. Süleyman Demirel Üniversitesi İktisadi ve İdari Bilimler Fakültesi, 5(2), 155-168.

Çeler, A. (2015) Tıp fakültesindeki araştırma görevlilerinde depresyon düzeyinin iş doyumu ile ilişkisinin incelenmesi. Konuralp Tip Dergisi, 7(3), 125-133.

David, D. J., Weiss vd. (1967). Manual for the Minnesota Satisfaction Questionnaire. Minnesota Studies in Vocational Rehabilitation XXII. Minneapolis: University of Minnesota.

Doğar, N. (2016). Kişilik ile iş tatmini arasındaki ilişkilerin incelenmesi: Bankacıllk sektöründe bir alan araştırmas1. Atatürk Üniversitesi Sosyal Bilimler Enstitüsü Dergisi, 20(4), 1237-1247.

Erdoğan, İ. (1999). İşletme yönetiminde örgütsel davranış. İstanbul: İ.Ü İşletme Fakültesi İşletme İktisadı Enstitüsü Araştırma ve Yardım Vakfı Yay.

Ferguson, K., Frost, L. and Hall, D. (2012). Predicting teacher anxiety, depression and job satisfaction. Journal of Teaching and Learning, 8(1), 27-41.

George, D. Ve Mallery, M. (2010). SPSS for windows step by step: A simple guide and reference. 17.0 Update. Boston: Pearson.

Güleç, C., (2009). Psikiyatrinin ABC'si. İstanbul: Say Yayınları.

Gürbüz, S. ve Şahin, F. (2016). Sosyal bilimlerde araştırma yöntemleri. Ankara: Seçkin Yayıncılık. 
Grant, A, M., ve Wrzeniewski A. (2010). I won't let you down... or will I? Core self- evaluations, other orientation, anticipated guilt and gratitude and job performance. Journal of Applied Psychology, 95(1), 108-121.

Govardhan, L. M., Pinelli, V. ve Schnatz, P. F. (2012). Burnout, depression and job satisfaction in obstetrics and gynecology residents. Connecticut Medicine, 76(7), 389-395.

Hisli, N. (1989). Beck depresyon ölçeğinin üniversite öğrencileri için geçerliği güvenilirliği. Türk Psikiyatri Dergisi, 7(23), 3-13.

Hagan, J. ve Kay, F. (2007). Even lawyer get the blue: Gender, depression and job satisfaction in legal practice. Law and Society Review, 41(1) 51-78.

Ilgaz Yıldırım, B., Gülmez, M. ve Yıldırım, F. (2016). The relationship between the five-factor personality traits of workers and their job satisfaction: A study on five star hotels in Alanya. Procedia Economics and Finance, 39, 284-291.

John, O. P., ve Srivastava, S. (1999). The big five trait taxonomy: History, measurement, and theoretical perspectives. In L. A. Pervin \& O. P. John (Eds.), Handbook of personality: Theory and research. New York, NY, US: Guilford Press, 102-138.

John, O. P., Donahue, E. M., ve Kentle, R. L. (1991). The big-five inventory-version 4a and 54. CA,

Berkeley: Berkeley Institute of Personality and Social Research.

Judge, T.A., Heller, D. ve Mount, M. K. (2002). Five-factor model of personality and job satisfaction: A meta-analysis. Journal of Applied Psychology, 87(3),530-541.

Kardaş, S. ve Şencan, H. (2018). Beş faktör kişilik özelliklerinin iş tatmini üzerindeki etkisi. İstanbul Ticaret Üniversitesi Sosyal Bilimler Dergisi, 17(33),287-299.

Kendler, K. S. ve ark. (2006). Personality and major depression. Arch Gen Psychiatry, 63, 11131118.

Koorevaar, A. M.; Comijs, H. C.; Dhond, A. D.; van Marwijk, H. W.; van der Mast, R.C, Naarding, P.; and Stek, M. L. (2013). Big five personality and depression diagnosis, severity and age of onset in older adults. Journal of Affective Disorders, 151, 178-185.

Köroğlu, E. (2014). Kişilik bozuklukları. Ankara: HBY Basım Yayın.

Llyod, S., Streiner, D. ve Shannon, S. (1994). Burnout, depression, life and job satisfaction among canadian emergency physicians. The Journal of Emergency Medicine, 12(4), 559-564.

McCrae, R.R. and Costa, P.T. (1987). Validation of the five factor model of personality across instruments and observers. Journal of Personality and Social Psychology, 52, 81-90.

Mustata, G. T. and Gregory, R. J. (2009). Depression treatment strategies and management. Second Edition. UK: Informa.

Özdayı, N. (1991). Liselerde görev yapan öğretmenlerin eğitim ortamlarının iş tatmini ve verimlilik açısından değerlendirilmesi. Marmara Üniversitesi Atatürk Eğitim Fakültesi Ĕgitim Bilimleri Dergisi, 10, 237-251.

Rothmann, S. ve Coetzer, E. P. (2003). The big personality dimension and job performance. SA Journal of Industrial Psychology, 29(1), 68-74.

Schmitt, D.P., Allik, J., McCrae, R.R. Ve Benet-Martinez, V. (2007) The geographic distribution of big five personality traits: Pattern and profiles of human self-description across 56 nations. Journal of Cross-Cultural Psychology, 38(2), 173-212.

Sevi, E.S. (2009). Psikobiyolojik kişilik modeli ve beş faktör kişilik kuramı: Mizaç ve karakter envanteri (TCI) ile beş faktör kişilik envanterinin (5FKE) karşılaştırılması. Yayımlanmamış yüksek lisans tezi. Ege Üniversitesi, İzmir.

Sığrı, Ü. ve Gürbüz, S. (2015). Örgütsel davranış. İstanbul: Beta Yayıncılık. 
Sobel, M.E. (1982). Asymptotic confidence intervals for indirect effects in structural equation models. In S. Leinhardt (Ed) Sociological Methodology. Washington DC: American Sociological Association.

Somer, O. (1998). Türkçe'de kişilik özelliği tanımlayan sıfatların yapısı ve beş faktör modeli. Türk Psikoloji Dergisi, 13(42), 17-32.

Steunenberg, B. ve ark. (2006). Personality and the onset of depresion in late life. Journal of Affective Disorders, 92, 243-251.

Sümer, N., Sümer, H.C. (2005). Beş faktör kişilik özellikleri ölçeği. Yayımlanmamış çalışma.

Şar, V., (2009). Psikiyatri. (Ed. Işın B. Kulaksızoğlu, Raşit Tükel, Alp Üçok, İlhan Yargıç, Olcay Yazıc1). İstanbul: İstanbul Üniversitesi Basım ve Yayınevi.

Tegin, B. (1980). Depresyonda bilişsel bozukluklar: Beck modeline göre bir incelemek. Yayınlanmamış doktora tezi. Hacettepe Üniversitesi Sosyal Bilimler Enstitüsü, Ankara.

Weiss, D.J., Dawis, R.V. England, G. W. ve Lofquist, L. H. (1967). Manual for the Minnesota Satisfaction Questionnaire. Vol. 22, Minnesota Studies in Vocational Rehabilitation, Minneapolis: University of Minnesota, Industrial Relations Center. 